\title{
ШТРИХИ ДО ЖИТТЄВОГО ШЛЯХУ ТА НАУКОВОГО ДОРОБКУ ПРОФЕСОРА ОРЕСТА ЛАВРЕНТІЙОВИЧА ГРОМА З НАГОДИ 75-РІЧЧЯ ВІД ДНЯ НАРОДЖЕННЯ
}

Орест Лаврентійович народився 23 серпня 1943 р. у селі Доброводи в одному з найбільших і наймальовничіших сіл Збаражчини Тернопільської області, що на річці Гніздечна біля підніжжя Зубової гори. Хлопець зростав і виховувався в сім'ї відомого скульптора, члена Спілки художників України Лаврентія Борисовича Грома, роботи якого зберігаються у Національному музеї імені Андрея Шептицького у Львові, та вчительки Ірини Дмитрівни Гром (у дівоцтві - Фесолович). Бабуся з батькової сторони в молоді роки працювала в маєтку Косачів, батьків Лесі Українки, від яких отримала у подарунок рушник, вишитий Лесею Українкою, котрий став сімейною реліквією.

Після Другої світової війни у 1946 р. родина Громів переїхала у Львів, де пройшло все життя Ореста Лаврентійовича.

1960 р. після закінчення зі срібною медаллю середньої школи № 62 м. Львова Орест Гром вступив у Львівський державний медичний інститут на фрармацевтичний фракультет. Здобувши фрах провізора, він понад два роки (1965 - 67 рр.) викладав у Коломийському фрармацевтичному училищі.

За спогадами Романа Лаврентійовича - рідного брата О. Л. Грома, він ще «студентом не приховував свого захоплення хімією, яка йому завжди подобалася, старанно і прискіпливо вивчав формули та аналізував механізми хімічних реакцій, часто до пізньої ночі засиджуючись за підручниками». У 1967 р. Орест Лаврентійович вступив в аспірантуру при кафредрі фрармацевтичної хімії Львівського державного медичного інституту, навчання в якій під керівництвом відомого науковця - профр. М. М. Туркевича успішно завершив захистом у 1971 р. кандидатської дисертаційної роботи «Синтез і перетворення похідних тіазолідиндіон2,4-гідразону-4». Орест Лаврентійович став п'ятдесятим учнем свого наукового керівника.

Після закінчення аспірантури у 1970 р. Ореста Грома скерували на кафредру організації та економіки фармації (ОЕФ), з якою був тісно пов'язаний увесь подальший шлях. На кафедрі він працював асистентом (1970-1977 рр.), доцентом (1977-1983 рр.) та завідувачем (1983-2012 рр.). Про перші кроки на кафредрі ОЕФ розповідає однокурсник і друг О. Л. Грома, проф. В. П. Музиченко: «Маючи фах хімічного профрілю, навчальні дисципліни, що викладалися на цій кафредрі, спочатку здалися йому нецікавими, й він деякий час нарікав на це. Проте Орест Лаврентійович швидко увійшов у курс справи й став одним із провідних організаторів фрармації України». Велика заслуга у цьому тодішнього завідувача кафредри ОЕФ проф. Р. М. Піняжка.

Завдяки власній ерудиції, організаторським здібностям та досвіду О.Л.Гром швидко зумів стати лідером кафедри ОЕФ, не тільки зберегти і примножити традиції попередників, але й започаткувати новий етап в ії розвитку як багатопрофрільного осередку методології і практики управлінсько-економічних дисциплін фрармацевтичного спрямування, а також сорормувати ділову та доброзичливу
колективі. Усе це сприяло зростанню наукового потенціалу кафедри ОЕФ, її методичної роботи, підвищенню авторитету як серед студентів, так і в середовищі однопрофільних кафедр закладів вищої освіти України.

Варто виділити особливу поміркованість і самобутню наукову толерантність Ореста Лаврентійовича щодо своїх учнів, він уважно і вдумливо вислуховував кожну думку свого дисертанта, оцінював її перспективність, а вже потім означував власні побажання. Учні Ореста Лаврентійовича, доценти Ганна Гасюк та Олександра Корнієнко, згадують: «Його поради й настанови були справжніми, мали глибокий зміст, з усієї рутини він вибирав те, що дійсно важливе. Ми ще досі користуємось «правилом трьох цвяшків» (тобто на перше місце ставити й виконувати те, що на даний час $€$ найголовнішим, а що може і почекати)».

Під керівництвом Ореста Лаврентійовича захищено 10 дисертації на здобуття наукового ступеня кан-

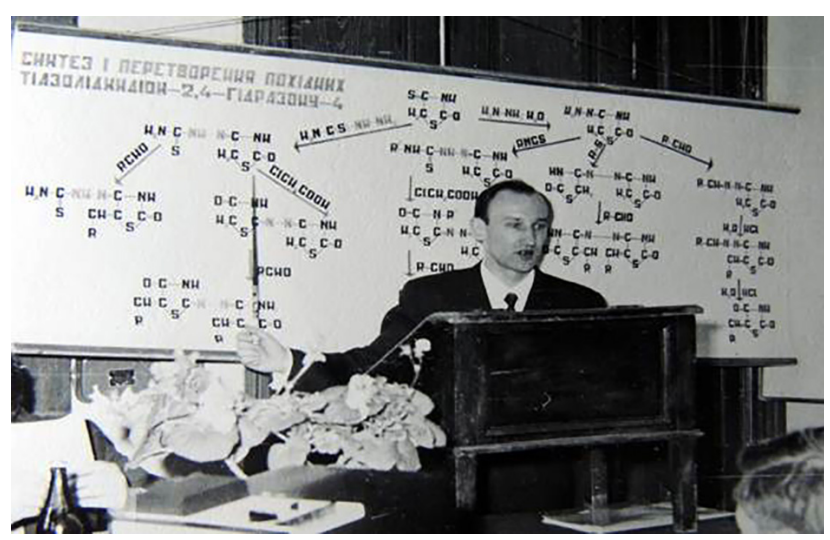

Блискучий захист дисертації О. Л. Громом, 1971 р.

ISSN 2312-0967. Фармацевтичний часопис. 2018. № 3 


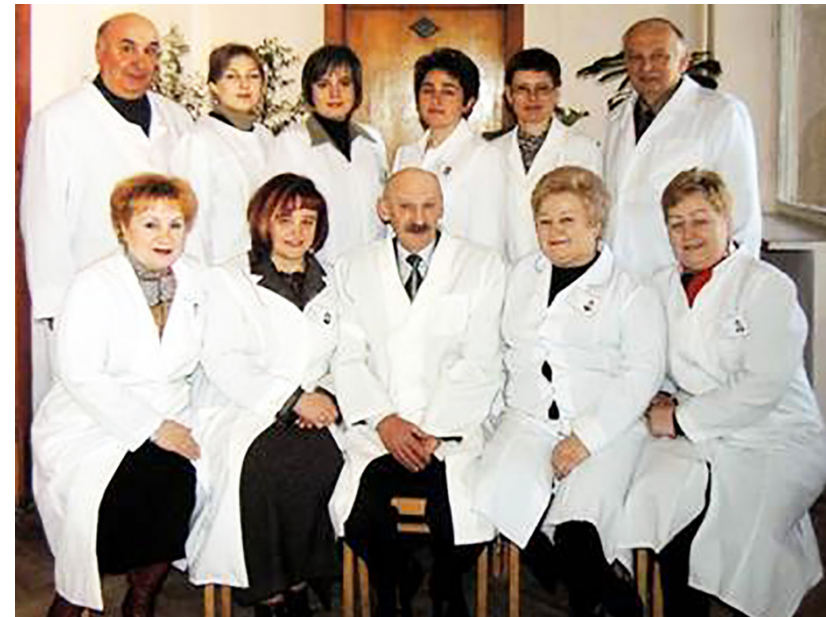

Колектив кафедри ОЕФ, 2006 р.: Богданна Геринович, Наталія Ярко, Орест Гром, Ганна Гасюк, Софрія Терещук (сидять), Володимир Комар, Наталія Ханик,

Ірина Чухрай, Оксана Левицька, Ірина Городецька, Андрій Дацко (стоять).

дидата фрармацевтичних наук - Д. В. Дикуном (1985 р., співкерівник - проф. Р. М. Піняжко), Б. П. Громовиком (1988р.), Г. Д. Гасюк (1989р.), Н. Б. Ярко (1990р.), О.М.Фойдер (співкерівник профр. Ф. А. Жогло), М. Л. Сятинею та І. Я. Городецькою (усі - 1997 р.), О. Р. Левицькою (1998 р.), Н. Л. Ханик (2009р.) та Д. Т. Грушковською (2011 р.). Більшість учнів працює на кафедрі, яку Орест Лаврентійович очолював упродовж майже 30 років.

За вагомий внесок у розвиток фрармацевтичної освіти й наукових досліджень у 2000 р. Оресту Грому було присвоєне вчене звання професора.

Результати науково-педагогічної діяльності профр. О. Л. Грома знайшли своє втілення у майже 300 наукових та навчально-методичних працях, серед них два навчальні посібники та 9 монографрій і довідників. Поміж досягнень Ореста Лаврентійовича та його учнів:

- проектування та організація першої в Україні навчально-виробничої аптеки (1992р.) та оптимізація навчального процесу на її базі;

- теоретичне обґрунтування та практична реалізація шляхів удосконалення роботи служби з контролю якості лікарських засобів, управління фрармацевтичними кадрами, господарською діяльністю аптечних закладів і медикаментозним забезпеченням населення України в нових економічних умовах;

- наукове опрацювання організаційно-методичних засад використання рослин у гастроентерології, оптимізації лікарського забезпечення офтальмологічних та оториноларингологічних хворих, хворих на ревматоїдний артрит і туберкульоз.

За активної участі Ореста Лаврентійовича та з ініціативи профр. Р. М. Піняжка при кафедрі ОЕФ створено інститутську кіностудію, де викладачі разом зі студентами упродовж 1970 - 80 рр. зняли 6 навчально-методичних фрільмів.
Наступність профр. О. Л. Грома щодо свого попередника - профр. Р. М. Піняжка, і доповнення одне одного у науково-педагогічній творчості проявилося у завершенні кандидатської дисертації Д. В. Дикуна та у супроводженні до захисту кандидатської дисертації Т. С. Райкової, а також у підготовці та виданні спільно з Б. Л. Парновським та А. Й. Дацком навчального посібника «Основи й методи управління у фрармації»», який побачив світ у 1986 р., та за ідеологією, структурою і змістом матеріалу став прототипом для подальших навчальних видань з менеджменту у фрармації.

Організаційні здібності Ореста Лаврентійовича не залишалися поза увагою адміністрації інституту та фракультету. У 1974 р. О. Л. Грома призначили на посаду заступника декана фрармацевтичного факультету, яку він очолював до 1983 р.

За словами випускника фрармацевтичного фракультету 1965 р. В.В.Синяка: «Як заступник декана фрармацевтичного фракультету О. Л. Гром по-батьківськи піклувався про студентів, завжди заглиблювався в їх проблеми, мудрою порадою підказував як вийти 3 тієї чи іншої життєвої ситуації. За його порядність, людяність, молодь його любила». У свою чергу, випускник 1978 р. І. М. Венгринюк згадує, що «Орест Лаврентійович вимогливо, але з розумінням ставився до студентів, допомагав облаштовувати наше життя в гуртожитку № 5 та під час роботи у літній період у студентських трудових загонах. При ньому було започатковано студентське самоврядування, еоективно працювала студентська рада, художня самодіяльність».

Упродовж 1983 - 98 рр. він був членом спеціалізованої вченої ради у Львівському національному медичному університеті імені Данила Галицького із захисту дисертацій на здобуття наукового ступеня кандидата фрармацевтичних наук.

Орест Лаврентійович у 1966 р. одружився 3 Стефанією Адамівною Карплюк, з якою прожив до кінця життя. Свою майбутню дружину він зустрів у дворі рідногобудинку, вякомувонащездвомаоднокурсницями винаймали кімнату, навчаючись у Львівському музичнопедагогічному училищі імені Філарета Колесси. Подружжя Громів виростило і виховало сина Юрія та доньку Ярину. Згодом вони подарували їм чудових онуків: Мартусю, Анечку, Софрійку та Олечку.

На превеликий жаль, 21 березня 2012 р. на 69 році життя перестало битися серце професора Ореста Лаврентійовича Грома.

Учні, колеги й друзі, випускники фармацевтичного фракультету пам'ятають Ореста Лаврентійовича як талановитого вченого і керівника, здатного згуртувати навколо себе однодумців, який займав активну громадянську позицію, що органічно поєднувалося з чуйністю, доброзичливістю й небайдужістю. Пам'ятають про нього, бо він був непересічною особистістю, що просто любила життя і цінувала людей в ньому.

Богдан Громовик, Наталія Ярко, Микола Саранчук

ISSN 2312-0967. Pharmaceutical review. 2018. № 3 